\title{
Theory of Planned Behavior on Factors Affecting Tetanus Toksoid Immunization Uptake Among Pregnant Women in Boyolali, Central Java
}

\author{
Tiara Yumafita', Setyo Sri Rahardjo²), Rita Benya Adriani3) \\ 1)Masters Program in Public Health, Universitas Sebelas Maret \\ 2)Department of Public Health, Faculty of Medicine, Universitas Sebelas Maret \\ 3) School of Health Polytechnics, Surakarta
}

\begin{abstract}
Background: Tetanus is an infectious disease caused by Clostridium tetani bacteria. TT immunization in pregnant women can prevent neonatal deaths. Maternal and Neonatal Tetanus (MNT) has been among the most common life threatening consequences of unclean deliveries and umbilical cord care practices, and are indicators of inequity in access to immunization and other maternal, newborn, and child health services. The neonatal mortality rate was still high in Boyolali Regency, Central Java. The purpose of this study was to determine the factors of TT immunization uptake among pregnant women in Boyolali, Central Java, using Theory of Planned Behavior.

Subjects And Method: This was a cross sectional study conducted in Boyolali, Central Java, from November to December 2018. A sample 200 pregnant women from 25 community health centers was selected by simple random sampling and positioned at level 2 in a multilevel model analysis. Eight pregnant women were selected at random from each community health center. The dependent variable was TT immunization uptake. The independent variables were knowledge, education, influence of midwife private practice, parity, income, intention, attitude, perceived behavior control, and social norm. The data on immunization uptake was obtained from the medical record. The other data were collected by questionnaire. The data were analyzed by multilevel multiple logistic regression analysis.

Results: The use of TT immunization increased with better maternal knowledge $(b=1.47 ; 95 \% \mathrm{CI}=$ 0.02 to $2.92 ; \mathrm{p}=0.047)$, high maternal education $(\mathrm{b}=2.19 ; 95 \% \mathrm{CI}=0.64$ to $3.75 ; \mathrm{p}=0.006)$, influence of midwife private practice $(b=2.07 ; 95 \% \mathrm{CI}=0.41$ to $3.72 ; \mathrm{p}=0.014)$, parity $\geq 2(b=1.81$; $95 \% \mathrm{CI}=0.13$ to $3.5 ; \mathrm{p}=0.034)$, income $\geq$ minimum regional wage $(\mathrm{b}=1.95 ; 95 \% \mathrm{CI}=0.39$ to 3.50 ; $\mathrm{p}=0.014)$, strong intention $(\mathrm{b}=1.73 ; 95 \% \mathrm{CI}=0.11$ to $3.34 ; \mathrm{p}=0.035)$, positive attitude $(\mathrm{b}=2.11$; $95 \% \mathrm{CI}=0.17$ to $4.05 ; \mathrm{p}=0.033)$, strong perceived behavior control $(\mathrm{b}=3.84 ; 95 \% \mathrm{CI}=1.47$ to $6.20 ; \mathrm{p}<0.001)$, supportive social norm $(\mathrm{b}=2.26 ; 95 \% \mathrm{CI}=0.29$ to $4.23 ; \mathrm{p}=0.024)$. Community health center had a contextual effect on TT immunization uptake with ICC $=35.86 \%$.

Conclusion: The use of TT immunization increased with better maternal knowledge , high maternal education, influence of midwife private practice, parity $\geq 2$, income $\geq$ minimum regional wage, strong intention, positive attitude, strong perceived behavior control, supportive social norm. Community health center has a contextual effect on TT immunization uptake.
\end{abstract}

Keywords: TT immunization, knowledge,education, midwife private practice, parity, income, intention, attitude, perceived behavior control, social norm, pregnant women

\section{Correspondence:}

Tiara Yumafita, Masters Program in Public Health, Universitas Sebelas Maret, Jl. Ir. Sutami 362A, Surakarta 57126, Central Java, Indonesia. Email: Tiarayumafita8@gmail.com.

Mobile: +6281230492658.

\section{BACKGROUND}

Tetanus is a disease that can be prevented by vaccinein which tetanus is a non- communicable disease caused by the bacterium Clostridium Tetani (C. Tetani). Until now, neonatal deaths in the world are 
almost $14 \%$ caused by tetanus neonatorum (UNICEF, UNFPA, and WHO, 2010). In 1988, there were 780 thousand deaths worldwide due to neonatal tetanus (UNICEF Indonesia, 2016). However, in 2013, WHO estimated that neonatal tetanus killed around 49,000 newborns, a 94\% reduction from the situation in 1988 (WHO, 2017). Although there has been a decline in neonatal deaths due to tetanus neonatorum, this is still a problem for the MDG program, which is related to maternal and infant health. It is also a challenge with the SDGs program that it will ensure a healthy life and promote prosperity for all people of all ages by 2030, which is to prevent preventable infant and toddler deaths, by reducing neonatal mortality rates to 12 per 1,000 $\mathrm{KH}$ and mortality rates toddlers 25 per 1,000 KH (Ermalena, 2017).

Indonesia currently still has maternal and infant deaths due to tetanus neonatorum (WHO, 2017). Based on the Directorate General of P2P per 15 January 2017 (Data from January-December 2016) Indonesia, there are still cases of tetanus neonatorum, which are 14 cases and 6 of them have died. (Indonesian Ministry of Health, 2017).

In Central Java Province, in 2015, the neonatal mortality rate was 7.2 per 1 ,000 live births. One of the neonatal deaths in Central Java was caused by cases of tetanus neonatorum over the past five years. Although Boyolali District is not in the highest three of the highest neonatal deaths, Boyolali also still has high neonatal deaths of $85.37 \%$ per $1000 \mathrm{KH}$ (Central Java Health Office, 2015).

Based on preliminary studies conducted at the Boyolali Health Office, almost all public health centers in Boyolali donated infant deaths, namely 21 health centers in 2015. In 2017 neonatal deaths were 106, while maternal deaths in boyolali district in
2017 were 112. TT immunization coverage at women of reproductive age and pregnant women in Boyolali Regency in 2017 reported TT1 (99.1\%), TT2 (51.5\%), TT3 (20.3\%), TT4 (10.9\%), TT5 (8.5\%), TT2 + (91.0\%) (Dinkes Bo-yolali, 2017).

The purpose of this study was to determine the factors of TT immunization uptake among pregnant women in Boyolali, Central Java, using Theory of Planned Behavior

\section{SUBJECTS AND METHOD \\ 1. Study Design \\ This was an analytic observational study with a cross sectional design. It was con- ducted in Boyolali, Central Java.}

\section{Population and Samples}

The source population used in this study was pregnant women at the community health center in Boyolali, Central Java. A sample of 200 pregnant women was selected using simple random sampling.

\section{Study Variables}

The dependent variable was TT immunization uptake. The independent variables were knowledge, education, parity, income, intention, attitude, perceived behavior control, social norm, and strata of community health center.

\section{Operational Definition of Variables}

Knowledge was defined as pregnant women's knowledge about TT immunization. The measurement scale was continous and transformed into dichotomous, coded o for low and 1 for high.

Education was defined as the last formal education attained by pregnant women. The measurement scale was categorical, o for <senior high school and 1 for $\geq$ senior high school.

Midwife private practice was defined as a midwife's effort in influencing clients to provide health education/counseling regarding TT immunization. The measu- 
rement scale was continous and transformed into dichotomous, coded o for negative influence and 1 for positive influence.

Parity was defined as the number of births of a child that is owned by both living and dead mothers. The measurement scale was dichotomous, $o$ for 1 child and 1 for children $\geq 2$.

Family income was defined as income earned by a husband or wife as a family economic source. The measurement scale was continous and transformed into dichotomous, coded o for $<\operatorname{Rp~1,668,700~and~} 1$ for $\geq \operatorname{Rp} 1,668,700$.

Intention was defined as a construct that shows a person's psychological (cognitive) readiness to perform a behavior. The measurement scale was continous and transformed into dichotomous, coded o for negative (score <mean) and 1 for positive (score $\geq$ mean).

Perceived behavior control was defined as someone's beliefs about the availability of certain resources related to the occurrence of behavior. The measurement scale was continous and transformed into dichotomous, coded o for negative (score $<$ mean) and 1 for positive (score $\geq$ mean).

Attitude was defined as the tendency of the mother to respond, assess, or express, both in the form of beliefs, feelings or behavior, to an idea, object, person, event or situation that is socially important. The measurement scale was continous and transformed into dichotomous, coded o for negative (score <mean) and 1 for positive (score $\geq$ mean).

Social norm was defined as standard rules that apply to a cultural social group that is used to decide whether a person's behavior is right (right) or not feasible (wrong) to be done.
TT immunization was defined as giving immunity to tetanus to pregnant women and babies in their womb. The measurement scale was categorical, o for incomplete TT immunization and 1 for complete TT immunization.

Community health center accreditation was defined as an acknowledgment from accreditation commission or Ministry of Health regarding the system for administering services and quality management of community health center in accordance with established standards.

\section{Data Analysis}

Univariate data analysis was performed to see the frequency distribution and the percentage of characteristics of the research subjects. Bivariate analysis was conducted to study the relationship between the use of TT immunization and independent variables using the Chi square test. Multivariate multiple logistic regression analysis was performed using multilevel analysis.

\section{Research Ethics}

Research ethics include the approval of research informed consent, anonymity, confidentiality, and ethical clearance. Ethical research was obtained from Faculty of Medicine, Universitas Sebelas Maret, with number 371 / UN27.6 / KEPK / 2018.

\section{RESULTS \\ 1. Univariate analysis}

Table 1 showed the results of univariate analysis. Table 1 showed that most of the study subjects had high knowledge (71.0\%), had high education $(75.5 \%)$, had 2 children (73.5\%), had family income $\geq$ minimum regional wage $(74.5 \%)$, had positive intention (73.0\%), had positive attitude (71.0\%), had strong perceived behavior control (84.5\%), and had positive subjective norm (78.0\%). 
Table 1. The results of univariate analysis

\begin{tabular}{|c|c|c|}
\hline Variable & $\mathbf{n}$ & $\%$ \\
\hline \multicolumn{3}{|l|}{ Knowledge } \\
\hline Poor $(<$ mean $)$ & 58 & 29.0 \\
\hline Good ( $\geq$ mean) & 142 & 71.0 \\
\hline \multicolumn{3}{|l|}{ Education } \\
\hline Low (<senior high school) & 49 & 24.5 \\
\hline High ( $\geq$ senior high school) & 151 & $75 \cdot 5$ \\
\hline \multicolumn{3}{|l|}{ Midwife private practice } \\
\hline Negative $(<$ mean $)$ & 44 & 22.0 \\
\hline Positive( $\geq$ mean) & 156 & 78.0 \\
\hline \multicolumn{3}{|l|}{ Parity } \\
\hline 1 child & 53 & 26.5 \\
\hline Children $\geq 2$ & 147 & 73.5 \\
\hline \multicolumn{3}{|l|}{ Income } \\
\hline$<$ Minimum wage $(<\operatorname{Rp} 1,668,700)$ & 51 & 25.5 \\
\hline$\geq$ Minimum wage ( $\geq$ Rp $1,668,700$ ) & 149 & 74.5 \\
\hline \multicolumn{3}{|l|}{ Intention } \\
\hline Negative $(<$ mean $)$ & 54 & 27.0 \\
\hline Positive ( $\geq$ mean) & 146 & 73.0 \\
\hline \multicolumn{3}{|l|}{ Attitude } \\
\hline negative $(<$ mean $)$ & 58 & 29.0 \\
\hline positive ( $\geq$ mean) & 142 & 71.0 \\
\hline \multicolumn{3}{|l|}{ perceived behavior control } \\
\hline Negative $(<$ mean $)$ & 31 & 15.5 \\
\hline Positive ( $\geq$ mean) & 169 & 84.5 \\
\hline \multicolumn{3}{|l|}{ Social Norm } \\
\hline Negative (< mean) & 44 & 22.0 \\
\hline Positive( $\geq$ mean $)$ & 156 & 78.0 \\
\hline
\end{tabular}

\section{Bivariate analysis}

Table 2 showed the results of bivariate analysis. Table 2 showed that there was a relationship between knowledge and the TT immunization uptake. High knowledge increased the likelihood of TT immunization uptake $(\mathrm{OR}=7.37 ; 95 \% \mathrm{CI}=3.50$ to $15.5 ; \mathrm{p}<0.001)$.

There was a significant relationship between education and TT immunization uptake. High education increased the likelihood of TT immunization uptake $(\mathrm{OR}=11.1 ; 95 \% \mathrm{CI}=5.12$ to $24.1 ; \mathrm{p}<0.001)$.

There was a significant relationship between midwife private practice and TT immunization uptake. Good midwife private practice increased the likelihood of
TT immunization uptake $(\mathrm{OR}=4.39 ; 95 \%$ $\mathrm{CI}=2.09$ to $9.23 ; \mathrm{p}<0.001$ ).

There was a significant relationship between parity and TT immunization uptake. High parity increased the likelihood of $\mathrm{TT}$ immunization uptake $(\mathrm{OR}=4.5 \mathrm{O}$; 95\% $\mathrm{CI}=2.19$ to $9.27 ; \mathrm{p}<0.001)$.

There was a significant relationship between income and TT immunization uptake. High income increased the likelyhood of TT immunization uptake $(\mathrm{OR}=$ $5.62 ; 95 \% \mathrm{CI}=2.70$ to $11.6 ; \mathrm{p}<0.001)$.

There was a significant relationship between intention and TT immunization uptake. Strong intention increased the likelihood of TT immunization uptake $(\mathrm{OR}=5.68 ; 95 \% \mathrm{CI}=2.74$ to $11.7 ; \mathrm{p}<0.001)$. 
There was a significant relationship between attitude increased the likelihood of TT immunization uptake $(\mathrm{OR}=4.25 ; 95 \%$ $\mathrm{CI}=2.08$ to $8.69 ; \mathrm{p}<0.001$ ).

There was a significant relationship between perceived behavior control and TT immunization uptake. Strong perceived behavior control increased the likelihood of
TT immunization uptake $(\mathrm{OR}=6.99 ; 95 \%$ $\mathrm{CI}=3.06$ to $15.9 ; \mathrm{p}<0.001$ ).

There was a significant relationship between social norm and TT immunization uptake. Positive social norm increased the likelihood of TT immunization uptake $(\mathrm{OR}=3.80 ; 95 \% \mathrm{CI}=1.81$ to $7.99 ; \mathrm{p}<0.001)$.

Table 2. The results of Chi-Square test

\begin{tabular}{|c|c|c|c|c|c|c|c|c|}
\hline \multirow{3}{*}{ Independent Variables } & \multicolumn{4}{|c|}{ TT Vaccine } & \multirow{3}{*}{ OR } & \multicolumn{2}{|c|}{ CI 95\% } & \multirow{3}{*}{$\mathbf{p}$} \\
\hline & \multicolumn{2}{|c|}{ Incomplete } & \multicolumn{2}{|c|}{ Complete } & & \multirow{2}{*}{$\begin{array}{c}\text { Lower } \\
\text { limit }\end{array}$} & \multirow{2}{*}{$\begin{array}{l}\text { Upper } \\
\text { limit }\end{array}$} & \\
\hline & $\mathbf{n}$ & \% & $\mathbf{n}$ & \% & & & & \\
\hline \multicolumn{9}{|l|}{ Knowledge } \\
\hline Low $(<$ mean $)$ & 27 & 64.3 & 31 & 19.6 & $7 \cdot 37$ & 3.50 & 15.5 & $<0.001$ \\
\hline $\operatorname{High}(\geq$ mean $)$ & 15 & $35 \cdot 7$ & 127 & 80.4 & & & & \\
\hline \multicolumn{9}{|l|}{ Education } \\
\hline Low (<senior high school) & 27 & 64.3 & 22 & 13.9 & 11.1 & 5.12 & 24.1 & $<0.001$ \\
\hline High ( $\geq$ senior high school) & 15 & 35.7 & 136 & 86.1 & & & & \\
\hline \multicolumn{9}{|l|}{ Midwife private practice } \\
\hline Negative $(<$ mean $)$ & 19 & 45.2 & 25 & 15.8 & 4.39 & 2.09 & 9.23 & $<0.001$ \\
\hline Positive ( $\geq$ mean) & 23 & 54.8 & 133 & 84.2 & & & & \\
\hline \multicolumn{9}{|l|}{ Parity } \\
\hline 1 child & 22 & 52.4 & 31 & 19.6 & 4.50 & 2.19 & 9.27 & $<0.001$ \\
\hline children $\geq 2$ & 20 & 47.6 & 127 & 80.4 & & & & \\
\hline \multicolumn{9}{|l|}{ Income } \\
\hline$<$ minimum wage & 23 & 54.8 & 28 & 17.7 & 5.62 & 2.70 & 11.6 & $<0.001$ \\
\hline$\geq$ minimum wage & 19 & 45.2 & 130 & 82.3 & & & & \\
\hline \multicolumn{9}{|l|}{ Intention } \\
\hline Negative $(<$ mean $)$ & 24 & 57.1 & 30 & 19.0 & 5.68 & 2.74 & 11.7 & $<0.001$ \\
\hline Positive ( $\geq$ mean) & 18 & 42.9 & 128 & 81.0 & & & & \\
\hline \multicolumn{9}{|l|}{ Attitude } \\
\hline Poor $(<$ mean $)$ & 23 & 54.8 & 35 & 22.2 & 4.25 & 2.08 & 8.69 & $<0.001$ \\
\hline Good ( $\geq$ mean) & 19 & 45.2 & 123 & 77.8 & & & & \\
\hline \multicolumn{9}{|l|}{$\begin{array}{l}\text { Perceived behavior } \\
\text { control }\end{array}$} \\
\hline Negative (< mean) & 17 & 40.5 & 14 & 8.9 & 6.99 & 3.06 & 15.9 & $<0.001$ \\
\hline Positive ( $\geq$ mean) & 25 & 59.5 & 144 & 91.1 & & & & \\
\hline \multicolumn{9}{|l|}{ Social Norm } \\
\hline Negative $(<$ mean $)$ & 18 & 42.9 & 26 & 16.5 & 3.80 & 1.81 & 7.99 & $<0.001$ \\
\hline Positive $(\geq$ mean $)$ & 24 & 57.1 & 132 & 83.5 & & & & \\
\hline
\end{tabular}

\section{Multilevel analysis}

Table 3 showed the results of multilevel analysis. Table 3 showed that there was a positive effect of knowledge and the use of TT immunization among pregnant women. Pregnant women with high knowledge had a logodd to use TT immunization by 1.47 units higher than pregnant women with low knowledge $(\mathrm{b}=1.47 ; 95 \% \mathrm{CI}=0.02$ to 2.92 ; $\mathrm{p}=0.047)$.
There was a positive effect of education and TT immunization uptake among pregnant women. Pregnant women with high education had a logodd to conduct TT immunization by 2.19 units higher than pregnant women with low education $(\mathrm{b}=$ 2.19; $95 \% \mathrm{CI}=0.64$ to $3.75 ; \mathrm{p}=0.006$ ).

There was a positive effect of midwife private practice and TT immunization uptake among pregnant women. Good midwife private practice had a logodd to 
conduct TT immunization by 2.07 units higher than poor midwife private practice $(b=2.07 ; 95 \% \mathrm{CI}=0.41$ to $3.72 ; \mathrm{p}=0.014)$.

There was a positive effect of parity and the use of TT immunization among pregnant women. Pregnant women who have parity $\geq 2$ had a logodd to conduct TT immunization by 1.81 units higher than pregnant women who have 1 parity $(b=$ $1.81 ; 95 \% \mathrm{CI}=0.13$ to $3.5 ; \mathrm{p}=0.034)$.

There was a positive effect of income and the use of TT immunization among pregnant women. Pregnant women with high income had a logodd to conduct TT immunization by 1.95 units higher than pregnant with low income $(b=1.95 ; 95 \%$ $\mathrm{CI}=0.39$ to $3.50 ; \mathrm{p}=0.014$ ).

There was a positive effect of intention and the use of TT immunization among pregnant women. Pregnant women with positive intention had a logodd to conduct TT immunization by 1.73 units higher than pregnant women with negative intention $(b=1.73 ; 95 \% \mathrm{CI}=0.11$ to $3.34 ; \mathrm{p}=0.035)$.

There was a positive effect of attitude and the use of TT immunization among pregnant women. Pregnant women with positive attitude had a logodd to conduct TT immunization by 2.11 units higher than pregnant women with negative attitude $(\mathrm{b}=$ 2.11; 95\% CI= 0.17 to $4.05 ; \mathrm{p}=0.033$ ).

There was a positive effect of perceived behavioral control and the use of TT immunization among pregnant women. Pregnant women with positive perceived behavioral control had a logodd to conduct TT immunization by 3.84 units higher than pregnant women with negative perceived behavioral control $(b=3.84 ; 95 \% \mathrm{CI}=1.47$ to $6.20 ; \mathrm{p}<0.001$ ).

There was a positive effect of social norm and the use of TT immunization among pregnant women. Pregnant women with positive social norm had a logodd to conduct TT immunization by 2.26 units higher than pregnant women with negative social norm $(b=2.26 ; 95 \% \mathrm{CI}=0.29$ to 4.23; $\mathrm{p}=0.024)$.

Ccommunity health center had strong contextual effect on TT immunization uptake with $\mathrm{ICC}=35.86 \%$.

Table 3. The results of multilevel analysis

\begin{tabular}{lcccc}
\hline \multicolumn{1}{c}{ Independent Variables } & \multicolumn{3}{c}{ CI 95\% } & p \\
Fixed Effect & b & $\begin{array}{c}\text { Lower } \\
\text { Limit }\end{array}$ & $\begin{array}{c}\text { Upper } \\
\text { Limit }\end{array}$ & \\
Knowledge (High) & & & & \\
Education ( $\geq$ senior high school) & 1.47 & 0.02 & 2.92 & 0.047 \\
Good midwife private practice & 2.19 & 0.64 & 3.75 & 0.006 \\
Parity (children $\geq$ 2) & 2.07 & 0.41 & 3.72 & 0.014 \\
Income $\geq$ Rp 1,668,700 & 1.81 & 0.13 & 3.5 & 0.034 \\
Intention (positive) & 1.95 & 0.39 & 3.50 & 0.014 \\
Attitude (positive) & 1.73 & 0.11 & 3.34 & 0.035 \\
Perceived Behavior Control (positive) & 2.11 & 0.17 & 4.05 & 0.033 \\
Social Norm (positive) & 3.84 & 1.47 & 6.20 & 0.001 \\
Random Effect & 2.26 & 0.29 & 4.23 & 0.024 \\
Community Health Center & & & & \\
N Observation = 200 & 1.83 & 0.22 & 14.9 & \\
N group = 25 & & & & \\
Log likehood= -39.4 & & & & \\
Prob> Chi2=.0.016 & & & & \\
ICC= 35.86\% & & & & \\
\hline
\end{tabular}




\section{DISCUSSION \\ 1. The effect of knowledge on the use of TT immunization}

The result of this study showed that there was a significant effect of knowledge on the use of TT immunization $(b=1.47 ; 95 \% \mathrm{CI}=$ 0.02 to $2.92 ; \mathrm{p}=0.047)$. Pregnant women with high knowledge had a logodd to conduct TT immunization by 1.47 units higher than pregnant women who have low knowledge.

The result of this study was supported by a study by Ayuningrum and Murdiyati (2013) which stated that pregnant women who have high knowledge would have a good understanding so that they would have complete immunization status. High maternal knowledge increased the use of TT immunization by 1.47 units, meaning that pregnant women who have high knowledge would conduct TT immunization by 1.47 times higher than those with low knowledge. According to Triratnasari (2013), knowledge was an important thing that must be seen to determine TT immunization status in pregnant women where knowledge increased self-awareness in TT immunization. Mothers who conduct complete TT immunization were mothers who have high knowledge.

The lack of knowledge and understanding about the benefit of vaccine affected maternal willingness to conduct immunization. Pregnant women who have good knowledge would be willing to do TT immunization because they considered the benefits of TT immunization which was to prevent the occurrence of tetanus disease for mothers and babies (William et al., 2018).

\section{The effect of maternal education} on the use of TT immunization

The result of this study showed that there was a significant effect of maternal education on the use of TT immunization $(b=2.19 ; 95 \% \mathrm{CI}=0.64$ to $3.75 ; \mathrm{p}=0.006)$. Pregnant women who have highlevel of education had a logodd to conduct TT immunization by 2.19 unitshigher than pregnant women who have low education. Triatnasari (2017 stated thatPregnant women who conduct TT immunization were pregnant women who have high level of education, because pregnant women have more experiences from the school so that they have good knowledge about the health of pregnant women, therefore, pregnant women would do TT immunization during pregnancy. Pregnant women who have higher education can increase the use of TT immunization by 2.19 units, meaning that pregnant women who have high level of education would use TT immunization by 2.19 times higher than pregnant women who have low level of education.

\section{The effect of maternal midwivery private practice on the use of TT immunization}

The result of this study showed that there was a significant effect of BPM on the use of TT immunization $(b=2.07 ; 95 \% \mathrm{CI}=0.41=$ to $3.72 ; \mathrm{p}=0.014$ ). Pregnant women who have good midwivery private practice effect had a logodd to conduct TT immunization by 2.07 units higher than pregnant women with poor midwivery private practice.

The result of this study was related to a study by Kriss et al., (2017), which stated that women who did not want to be vaccinated were women who have lack of recommendations from a doctor. It can be concluded that health education provided by health personnels which in this case was a midwife was useful to increase the use of immunization during pregnancy. Pregnant women who have a good BPM effect increased the use of TT immunization by 2.07 units. This mean that pregnant women who have a good effect on BPM would conduct TT immunization by 2.07 units 
higher than pregnant women who have lack of BPM effect.

\section{The effect of parity level on the use of TT immunization}

The result of this study showed that there was a significant effect of parity on the use of TT immunization $(b=1.81 ; 95 \% \mathrm{CI}=0.13$ to $3.5 ; \mathrm{p}=0.034)$. Pregnant women who have parity $\geq 2$ had a logodd to conduct TT immunization by 1.81 units higher than pregnant women who have 1 parity.

The result of this study was supported by a study done by Triratnasari (2017) which stated that mothers who have more than one children have better experiences from the previous pregnancy, so that their knowledge was broader and their mentality was better. Therefore, pregnant women would prepare their pregnancy and maintain their pregnancy properly, one of the efforts was by conducting TT immunization during pregnancy. Pregnant women who have parity $\geq 2$ can increase the use of TT immunization by 1.81 units, meaning that pregnant women who have parity of $\geq 2$ would conduct a complete TT immunization than pregnant women who have $<1$ parity.

\section{The effect of income on the use of TT immunization}

The result of this study showed that there was a significant effect of income on the use of TT immunization $(b=1.95 ; 95 \% \mathrm{CI}=0.39$ to $3.50 ; p=0.014)$. Pregnant women who have income $\geq \mathrm{MW}$ had a logodd to conduct TT immunization by 1.95 unitshigher than pregnant women who have income $<\mathrm{MW}$.

The result of this study was supported by a study by Oyefara (in Isnayni, 2017) which stated that socio-economics influenced the immunization status, because 90.9\% of mothers who have high socioeconomic status have fully immunized their children while only $45.3 \%$ of mothers with low socio-economic status who gave complete immunization to their children.

\section{The effect of intention on the use of TT immunization}

The result of this study showed that there was a significant effect of maternal intention on the use of TT immunization $(b=$ 1.73 ; $95 \% \mathrm{CI}=0.11$ to $3.34 ; \mathrm{p}=0.035$ ). Pregnant women who have positive intention had a logodd to conduct TT immunization by 1.73 unitshigher than pregnant women who have negative intention.

This study was in line with a study by William et al., (2018) which stated that pregnant women who have awareness initiatives were very helpful to increase the knowledge and reduce doubts to conduct immunization. Pregnant women who have high initiation or intention tend to conduct immunization.

\section{The effect of attitude on the use of TT immunization}

The result of this study showed that there was a significant effect of maternal attitude on the use of TT immunization $(b=2.11$; 95\% CI= 0.17 to $4.05 ; \mathrm{p}=0.033)$. Pregnant women who have good attitude had a logodd to conduct TT immunization by2.11 unitshigher than pregnant women who have poor attitude.

This study was in line with a study by wirda (2012) which stated thatattitude determined a person into a better one. A positive attitude would trigger a behavior of pregnant women to conduct tetanus toxoid immunization (Wirda in Triratnasari, 2017). Pregnant women who have a good attitude would increase the use of TT immunization by 2.11 units, meaning that pregnant women who have a good attitude would conduct TT immunization by 2.11 times higher compared to pregnant women who have poor attitude.

This study was in line with a study done by Macdougal et al., (2015) which 
stated that the attitude of pregnant women regarding vaccines during pregnancy showed that the majority of pregnant women strongly agree that it was better to be immunized during pregnancy to avoid the risk of disease that would occur in their babies.

\section{The effect of perceived behavior control on the use of TT immuni- zation}

The result of this study showed that there was a significant effect of perceived behavior control on the use of TT immunization $(\mathrm{b}=3.84 ; 95 \% \mathrm{CI}=1.47$ to $6.20 ; \mathrm{p}<0.001)$. Pregnant women who have positive perceived behavioral control had a logodd to conduct TT immunization by 3.84 units higher than pregnant women who have negative perceived behavioral control.

This study was in line with a study by William et al., (2018) which stated that the majority of mothers described the vaccine as a drug that was able to protect their children from disease, therefore, mothers support and conduct immunizations. Pregnant women who have a positive perceived behavioral control increased the use of TT immunization by 3.84 units, meaning that pregnant women who have positive perceived behavioral control would conduct immunization by 3.84 units higher than pregnant women who have negative perceived behavioral control.

\section{The effect of social norm on the use of TT immunization}

The result of this study showed that there was a significant effect of maternal social norm on the use of TT immunization $(b=$ 2.26; $95 \% \mathrm{CI}=0.29$ to $4.23 ; \mathrm{p}=0.024$ ). Pregnant women who have positive social normhad a logodd to conduct TT immunization by 2.26 units higher than pregnant women who have negative social norm.

This study was in line with a study by William et al. (2018) which stated that pregnant women who conduct TT immunization were influenced by community myths. Where the culture of the community toward immunization increased the acceptance of immunization. Pregnant women who have a positive social influence increased the use of TT immunization by 2.26 units, meaning that pregnant women who have a positive social influence would conduct TT immunization by 2.26 units higher than pregnant women who have negative social influences.

In Zambia, the campaign for vaccination in culture has become a standard of health promotion tool, this can encourage mothers to conduct immunization (William et al., 2018)

\section{The contextual effect of commu- nity health center on the use of TT immunization}

The result of this study showed that there was a contextual effect of health center level on the use of TT immunization with the score of ICC $=35.86 \%$. The variation in the use of TT immunization by $35.86 \%$ was determined by variables at the health center level. The ICC score in this study was greater than the rule of thumb by $8-10 \%$.

According to Minister of Health Republic of Indonesia number 75 of 2014, Community Health Center (Puskesmas) was a health service facility that organized public health efforts and first-rate individual health efforts, by prioritizing promotive and preventive efforts, to achieve the highest degree of public health in its working area.

The health development vision held by $\mathrm{CHC}$ was the achievement of healthy sub-districts towards the realization of a healthy Indonesia. Healthy indicators were: healthy environment, healthy behavior, quality of health services, and health status of sub-district residents. In order for CHC to carry out their functions optimally, they need to be managed properly, both the 
performance of services, the service process, and the resources used (Ministry of Health, 2014).

This study was in line with a study by Widayati et al., (2018) which stated that accredited health centers were able to provide services according to the standards. The relation with this research was that the majority of accredited health centers would help pregnant women to have complete immunization status compared to those that were not accredited, therefore, the majority of immunization status tend to be incomplete.

It is expected that the Boyolali District health office would improve and optimize the programs related to TT immunization, therefore, neonatal deaths can be prevented and increase the coverage of TT immunization.

\section{REFERENCES}

Ayuningrum IY, Murdiyati A (2013). Hubungan tingkat pengetahuan tentang imunisasi tetanus toksoid dengan kelengkapan imunisasi tetanus toksoid pada ibu hamil primigravida di Puskesmas Rowosari Semarang. Dinamika Kebidanan, 3(2).

Dinas Kesehatan Provinsi Jawa Tengah (2015). Profil Kesehatan Provinsi Jawa Tengah Tahun 2015. http://www.depkes.go.id>13_jateng_2015

Dinas Kesehatan Kabupaten Boyolali (2015). Profil Kesehatan Kabupaten Boyolali Tahun 2015. http://www.depkes.go.id $>$ download $>$ profil.

Ermalena (2017). Indikator kesehatan SDGs di Indonesia. Jakarta: Balai Kartini.

Isnayni E (2017). Hubungan pengetahuan ibu, pendapatan keluarga dan peran keluarga dengan status imunisasi dasar. Jurnal Berkala Epidemiologi, 4(3): 360-370.
Kementrian Kesehatan Republik Indonesia (2014). Standar Akreditasi Puskesmas. Jakarta: Kementrian Kesehatan RI. ISBN 978-602-235-731-5.

(2017). Data dan informasi profil kesehatan Indonesia 2016.

Kriss JL, Frew PM, Cortes M, Malik FA, Chamberlain AT, Seib K, Flowers L, Ault KA, et al. (2017). Evaluation of two vaccine education interventions to improve pertussis vaccination among pregnant African American women: a randomized controlled trial. Vaccine. 35(11): 1551-1558. doi: 10.1016/j.vaccine.2017.01.037.

MacDougall DM, Halperin BA, Langley JM, McNeil SA, Cameron DM, Li L, Halperin SA (2015). Knowledge, attitudes, beliefs, and behaviors of pregnant women approached to participate in a Tdap maternal immunization randomized, controlled trial. Journal Human Vaccines \& Immunotherapeutics. 12(4): 879-885. http://dx.doi.org/10.1080/21645515.2015.1130193.

Permenkes RI (2014). PMK No 75 Th 2014 ttg Puskesmas. http://www.aidsindonesia.or.id/uploads/20141210110659. PMK_No_75_Th_2014_ttg_Puskesm as.pdf.

(2017). Peraturan Menteri Kesehatan Republik Indonesia Nomor 28 Tahun 2017 tentang izin dan penyelenggaraan Praktik Bidan.

Triatnasari D (2017). Faktor yang berhubungan dengan pelaksanaan imunisasi tetanus difteri pada ibu hamil. Jurnal berkala epidemiologi, 5(3): 325-337.

UNICEF Indonesia (2016). PBB Mendeklarasikan Indonesia Eliminasi Tetanus Pada Ibu Dan Bayi : UNICEF. Jakarta. tersedia: https://www.unicef.org.

UNICEF, UNFPA, WHO (2010). Achieving and sustaining maternal and neonatal 
tetanus eliminasi: UNICEF,UNFPA, and WHO. http://www.who.int/immunization/diseases/MNTEStrategicPlan_E.pdf.

Widayati MY, Tamtomo D, Adriani RB (2018). Factors affecting quality of health service and patient satisfaction in community health centers in Nort Lampung, Sumatera. Journal Of Health Policy And Management, 2(2): 165-175. http://doi.org/10.26911/thejhpm.2017.02.02.08.

William AL, Mccloskey L, Mwale M, Mwananyanda L, Murray K, Herman AR, Thea DM, Macleod WB, Gill CJ
(2018). "When you are injected, the baby is protected: Assessing the acceptability of a maternal Tdap vaccine based on mothers' knowledge, attitudes, and beliefs of pertussis and vaccinations in Lusaka, Zambia. Vaccine 36: 3048-3053.

World Health Organization (2017). Maternal and Neonatal Tetanus Elimination (MNTE). http//www.who.int/immunization/diseases/MNTE_initiative/en/.

(2017). Imunisasi, Vaksin, Dan Biologi. http//www.who.int. 